\title{
Detection of Ostreopsis ovata from Eastern Sicily Coast Using SEM Microscopy Coupled to the Vibrio fischeri Test
}

Oliveri Conti G, Ledda C, Zuccarello M, Fiore M, Fallico R, Sciacca S and Ferrante $M^{\star}$

Department "GF Ingrassia" - Hygiene and Public Health. University of Catania, Italy.

\begin{abstract}
Algal blooms may occur in freshwater as well as marine environments. Typically only a small number of phytoplankton species are involved. There is an increase of monitoring plans in the world resulting from the increased impact from these harmful algal blooms. The harmful algal blooms had already been identified in the Mediterranean since 1990 but their presence has intensified in recent years. In particular the harmful algal blooms of genus Ostreopsis are detected in Mediterranean Sea. Aim of our study was to evaluate the presence of O. ovata during 2008, 2009 and 2010 years in samples of seawater and macroalgae from lonian coast by pattern recognition using scanning electron microscopy with microanalysis coupled with the Vibrio fischeri ecotoxicological test, to verify presence of toxicity. All samples of macroalgae observed by scanning electron microscopy with microanalysis showed an abundance of diatoms in the number and species. Only in three sampling sites the toxicity tests were positive (respectively $45 \%, 29 \%$ and $28 \%$ ). Our data showed that the harmful algal blooms are not a very frequent problem for the lonian coast, but they are occasional blooms and they not showed an immediate risk for economy related to the fish, shellfish and mussels.
\end{abstract}

To protect the exposed people's health is necessary to continue the monitoring and complete the preventive action through an adequate public information.

Keywords: Ostreopsis ovata, Harmful algal blooms, Vibrio fischeri, Mediterranean Sea, Risk

\section{Introduction}

Phytoplanktonic organisms have an important effect on the quality of water. Algal blooms may occur in freshwater as well as marine environments. With the global expansion of harmful algal blooms (HABs), several approaches have been undertaken to monitor its occurrence [1-3]. The dinoflagellates and diatoms are the most represented phylum and both can to produce a negative impact if they are present in densities that would cause HABs with consequent health and economic impact on the local population $[4,5]$. The reasons for HABs remain debated and include not only eutrophication, their occurrence in some locations appears to be entirely natural, while in others they appear to be a result of human activities. There is an increase of monitoring plans in the world (expanding routine coastal monitoring programs, deployment of new detection methods for individual species, for toxins and toxicities, ...) resulting from the increased impact from these HABs [6]. During the last decade, benthic dinoflagellates of the genus Ostreopsis have expanded their distribution from tropicalsubtropical to temperate waters, such as the Mediterranean Sea.

The presence of HABs in the Mediterranean Sea is an ecological problem but also economic because brings a negative impact on fish and mussels producing die-offs of fish stocks wild and farmed [4]. In this geographic area, in fact, the fish farms offshore have multiplied.

The HABs had already been identified in the Mediterranean since 1990 but their presence has intensified in recent years. The HABs, especially along the Italian coasts, are an increasingly common event and of difficult detection and management [7]. Furthermore, summer Ostreopsis ovata blooms mainly in Italian coasts have been recently associated with human irritations, resulting in considerable economic losses in the tourism industry and in economy related to the fish, shellfish and mussels.

In Italy only in 2008 was considered important to recommend the monitoring and surveillance of potentially affected areas to HABs

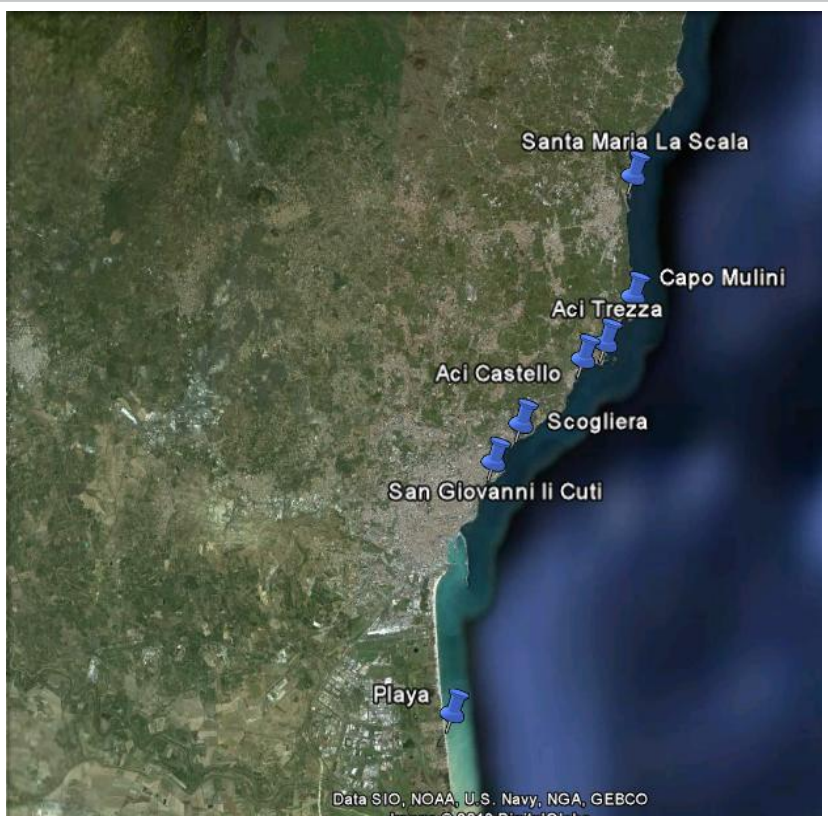

Figure 1: Location of the sampling areas in the lonian coast.

*Corresponding author: Ferrante M, Department "GF Ingrassia" - Hygiene and Public Health, University of Catania, Italy, Tel/Fax: +390953782186; E-mail: marfer@unict.it

Received July 15, 2011; Accepted November 12, 2011; Published November 21, 2011

Citation: Oliveri Conti G, Ledda C, Zuccarello M, Fiore M, Phallic R, et al (2011) Detection of Ostreopsis ovata from Eastern Sicily Coast Using SEM microscopy coupled to the Vibrio fischeri Test Development J Aquac Res S4: 001. doi:10.4172/2155-9546.S4-001

Copyright: ( 2011 Oliveri Conti G, et al. This is an open-access article distributed under the terms of the Creative Commons Attribution License, which permits unrestricted use, distribution, and reproduction in any medium, provided the original author and source are credited. 
Citation: Oliveri Conti G, Ledda C, Zuccarello M, Fiore M, Phallic R, et al. (2011) Detection of Ostreopsis ovata from Eastern Sicily Coast Using SEM microscopy coupled to the Vibrio fischeri Test Development J Aquac Res S4: 001. doi:10.4172/2155-9546.S4-001

Page 2 of 6

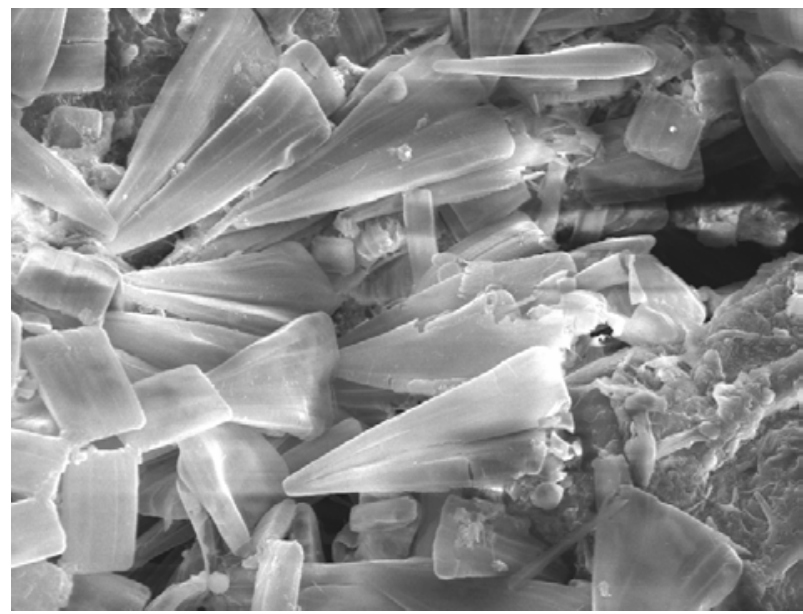

Figure 2: Sample of macroalgae rich in species of diatoms from Playa 2008.

Vibrio fischeri Toxicity (\%)

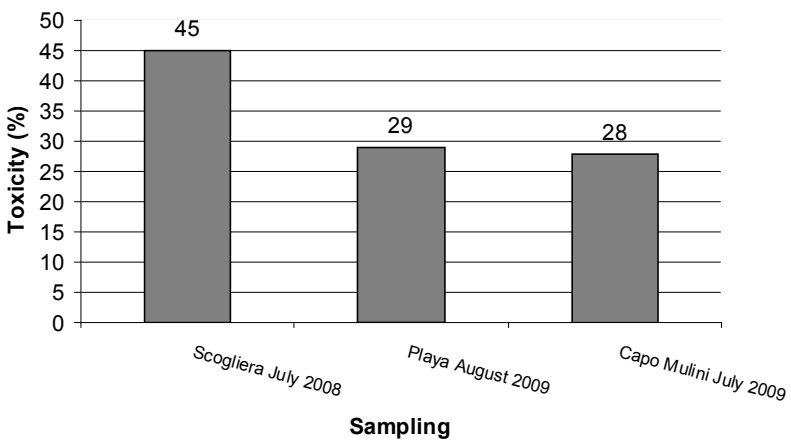

Figure 3: Positive samples tested for toxicity. All other location sampled have shown no toxicity.

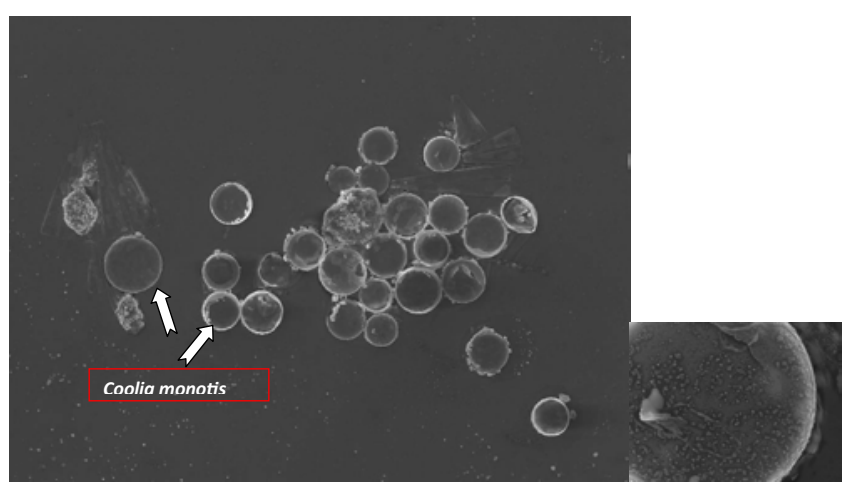

Figure 4: Specimens of Coolia monotis and structure of its frustule (see zoom) related to cooliatoxin a neurotoxic analog to yessotoxin.

[8-10]. The genus Ostreopsis (epiphytic, benthic and planktonic dinoflagellate) are detected in Mediterranean Sea and particularly in Sicily, Liguria, Tuscany, and Lazio [11-14]. The blooms of the genus Ostreopsis (Ostreopsis ovata and Ostreopsis siamensis) can be cause the release of palytoxin, among the most powerful and lethal marine toxins known, but also severe damage associated with exposure to marine aerosol rich in palytoxin. It is therefore evident that a routine monitoring strategy for these benthic species is essential in susceptible areas.

This research is part of a project of the University of Catania to monitor coastal waters of Catania city wetted by the Ionian Sea, in the past affected by reports and by toxic and non toxic blooms [15]

Aim of our study was to evaluate the presence of O. ovata in samples of seawater and macroalgae in the summer's months of 2008, 2009 and 2010 years by pattern recognition using scanning electron microscopy (SEM) with microanalysis coupled with the Vibrio fischeri ecotoxicological test, to verify possible presence of toxicity.

\section{Materials and Methods}

The ionian coast under study is characterized by sandy beaches, sand and gravel and basalt cliffs. The monitoring was conducted during summers of 2008, 2009 and 2010 years in the sampling sites shown in Figure 1, the choice of methodological approach of sampling was made on the basis of ministerial directives of Health Ministry [9-10] and ISPRA, Italian equivalent of USEPA, which requires one sample per month for the months of June, July, August and September.

Water samples were sampled near the coast (within 2 meters from the shoreline and a maximum depth of 1 meter). Two water samples were sampled, one sample $(500 \mathrm{ml})$ for microscopic investigation and one sample $(50 \mathrm{ml})$ for ecotoxicological test.

Sampling for macroalgae and ecotoxicological test was carried out by the collection of 3 aliquots (distributed along $10 \mathrm{~m}$ of the sampling site) to form a single representative sample of the under investigation site.

As soon as finished the sampling phase, both samples were brought in to the laboratory under controlled temperature condition. The sample of $500 \mathrm{ml}$ was fixed with $2 \mathrm{ml}$ of Lugol's solution (Carlo Erba). The sample of $50 \mathrm{ml}$ was immediately frozen $\left(-20^{\circ} \mathrm{C}\right)$. The samples of $500 \mathrm{ml}$ were filtered through $5 \mu \mathrm{m}$ nucleopore membrane filters. Filters were washed up with glass-distilledated water to remove any salts or debris. Filters with the phytoplankton were air dried, after which they were stuck onto aluminum stubs. Samples were then coated with gold using a Cressington Sputter Coater 108.

Samples of macroalgae for the microscopic determinations, were fixed with $2 \mathrm{ml}$ of Lugol's solution and prepared by the method indicated by Vitale et al. [16], the microscopic determination of macroscopic algae and water samples was carried out with SEM-EDXA Cambridge Instruments mod. Stereoscan 360 using operational parameters described by Vitale et al. [16].

Quantitation of the produced spectra by microanalysis from different cells was carried out using the Oxford INCA Energy software with cobalt as reference element.

The toxicity of the water samples $(50 \mathrm{ml})$ obtaining the quality of data were performed using the Microtox system (fully automated method which allows determination of toxic effects of chemicals on photoactive bacteria using inhibition of light emission of Vibrio fischeri 15-30 min.) managed in accordance with ISO 11348-3:2007. Bacteriea emit naturally light which originates in the organism through chemical reaction catalyzed with enzyme luciferase. Inhibition of light radiation emitting is assessed by bacteria exposed to suitable chosen toxicant concentrations. Decrease of bacterial luminiscence measured after 5 , 15 and 30 minutes of exposition serves as test endpoint. The tests were 
Citation: Oliveri Conti G, Ledda C, Zuccarello M, Fiore M, Phallic R, et al. (2011) Detection of Ostreopsis ovata from Eastern Sicily Coast Using SEM microscopy coupled to the Vibrio fischeri Test Development J Aquac Res S4: 001. doi:10.4172/2155-9546.S4-001

\begin{tabular}{|l|lllllllllll|}
\hline \multicolumn{19}{|l|}{ Processing option : Oxygen by stoichiometry (Nomalized) } \\
\hline Spectrum & In stats. & C & Na & Mg & Al & Si & S & Ca & O & Total \\
& & & & & & & & & & \\
Spectrum 1 & Yes & 26.07 & 0.61 & 0.47 & $\mathbf{0 . 0 8}$ & $\mathbf{0 . 3 5}$ & 0.19 & 0.62 & 71.01 & 100.00 \\
& & & & & & & & & & \\
Mean & & 26.07 & 0.61 & 0.47 & 0.08 & 0.35 & 0.19 & 0.62 & 71.01 & 100.00 \\
Std. deviation & & 0.00 & 0.00 & 0.00 & 0.00 & 0.00 & 0.00 & 0.00 & 0.00 & \\
Max. & & 26.07 & 0.61 & 0.47 & 0.08 & 0.35 & 0.19 & 0.62 & 71.01 & \\
Min. & & 26.07 & 0.61 & 0.47 & 0.08 & 0.35 & 0.19 & 0.62 & 71.01 & \\
All results in weight\% & & & & & & & & & \\
\hline
\end{tabular}

Table 1: The frustule of diatom is made up of quartzite or amorphous hydrated silica, which can be associated with small amounts of aluminum, iron and titanium. As can be seen from the table the silica is really too poor $(<3 \%)$ to be a diatom.

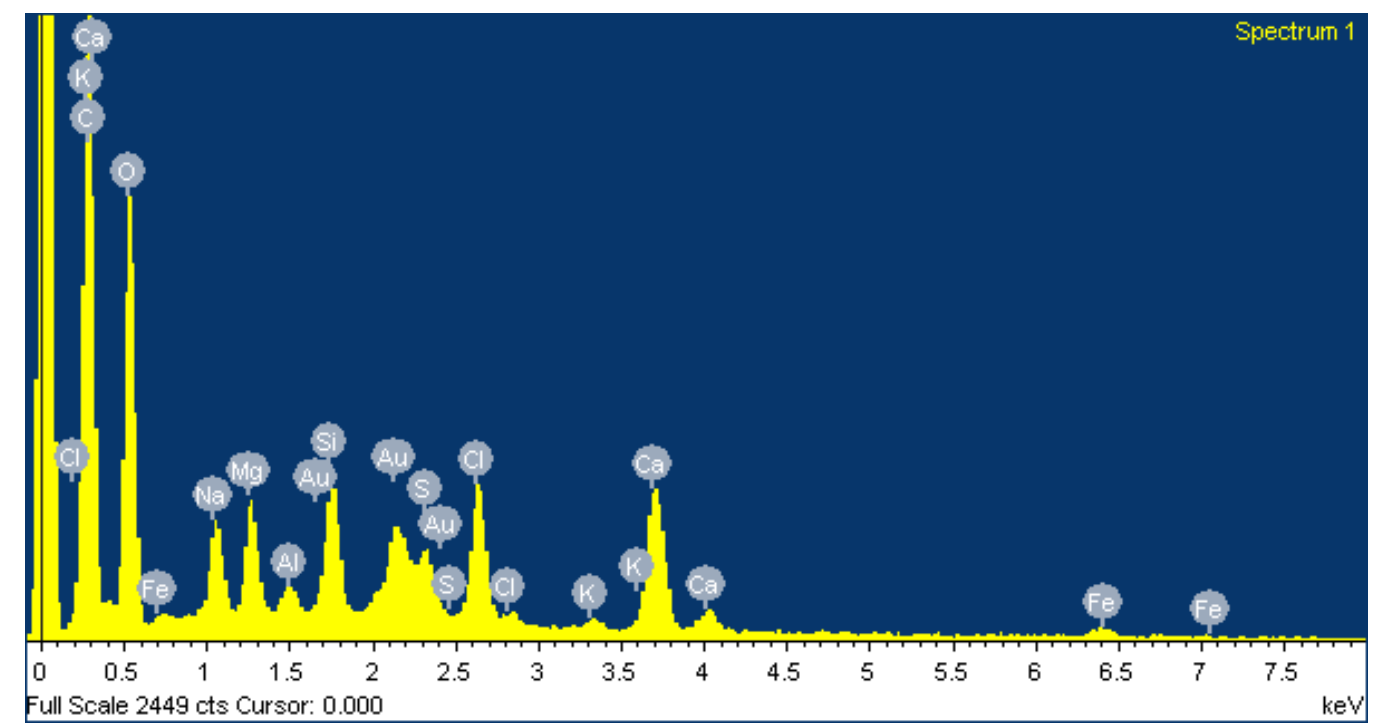

Figure 5: Microanalisis Spectrum Report of by Coolia monotis indicating the costitutive elements of cell (weight \%) (see Table 1).

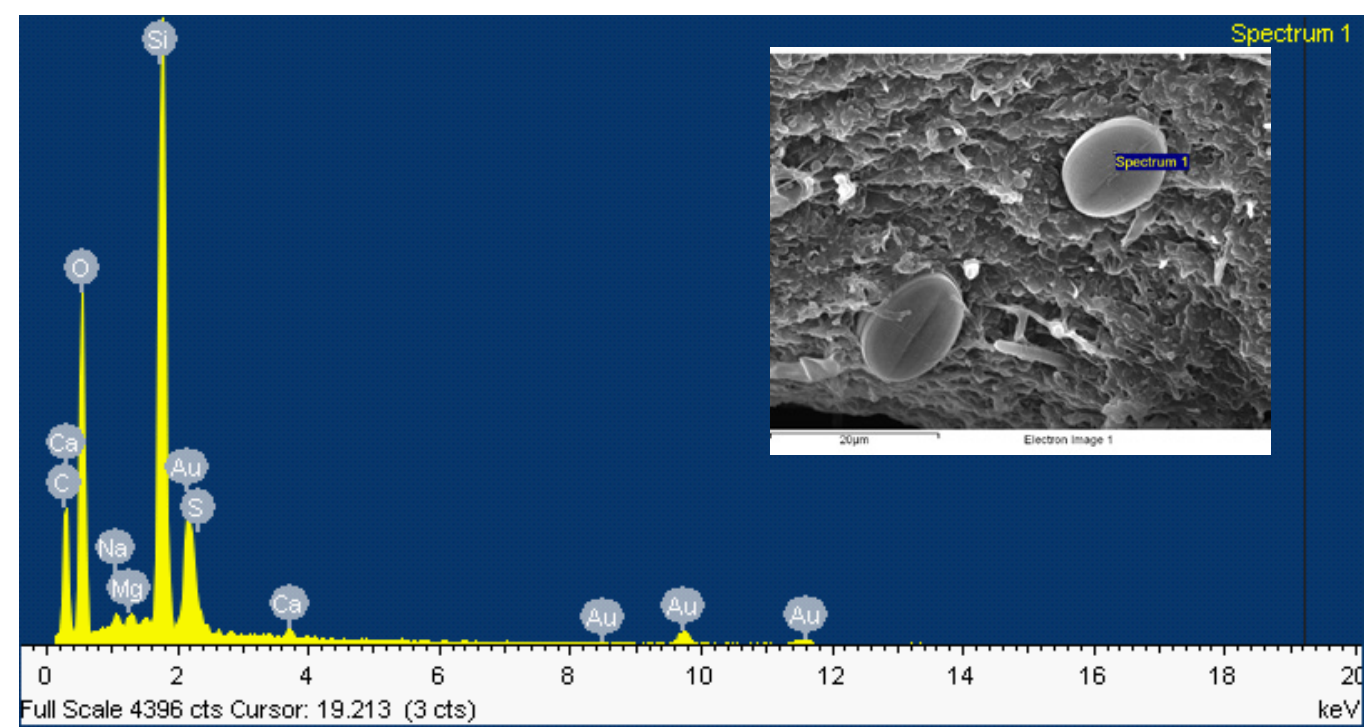

Figure 6: Microanalisis Spectrum Report of by Cocconeis scutellum indicating the costitutive elements of cell (weight \%) (see Table 2). 
Citation: Oliveri Conti G, Ledda C, Zuccarello M, Fiore M, Phallic R, et al. (2011) Detection of Ostreopsis ovata from Eastern Sicily Coast Using SEM microscopy coupled to the Vibrio fischeri Test Development J Aquac Res S4: 001. doi:10.4172/2155-9546.S4-001

Processing option : Oxygen by stoichiometry (Normalized)

\begin{tabular}{l|llllllllll}
\hline Spectrum & In stats. & C & Na & Mg & Al & Si & S & Ca & O & Total \\
Spectrum 1 & Yes & 21.47 & 0.37 & 0.29 & $\mathbf{0 . 1 1}$ & $\mathbf{8 . 9 1}$ & 0.31 & 0.24 & 68.31 & 100.00 \\
Spectrum 2 & Yes & 21.70 & 0.40 & 0.26 & $\mathbf{0 . 1 7}$ & $\mathbf{8 . 6 6}$ & 0.19 & 0.17 & 68.47 & 100.00 \\
& & & & & & & & & & \\
Mean & & 21.58 & 0.39 & 0.27 & $\mathbf{0 . 1 4}$ & $\mathbf{8 . 7 8}$ & 0.25 & 0.20 & 68.39 & 100.00 \\
Std. deviation & & 0.16 & 0.02 & 0.02 & $\mathbf{0 . 0 4}$ & $\mathbf{0 . 1 7}$ & 0.09 & 0.05 & 0.11 & \\
Max. & & 21.70 & 0.40 & 0.29 & 0.17 & 8.91 & 0.31 & 0.24 & 68.47 & \\
Min. & & 21.47 & 0.37 & 0.26 & 0.11 & 8.66 & 0.19 & 0.17 & 68.31 & \\
\hline
\end{tabular}

All results in weight $\%$

Table 2: The frustule of diatom (Cocconeis scutellum) is made up of quartzite or amorphous hydrated silica, which can be associated with small amounts of aluminum, iron and titanium. As can be seen from the table the silica is $>3 \%$ (double testing), the results indicate that it is a diatom.

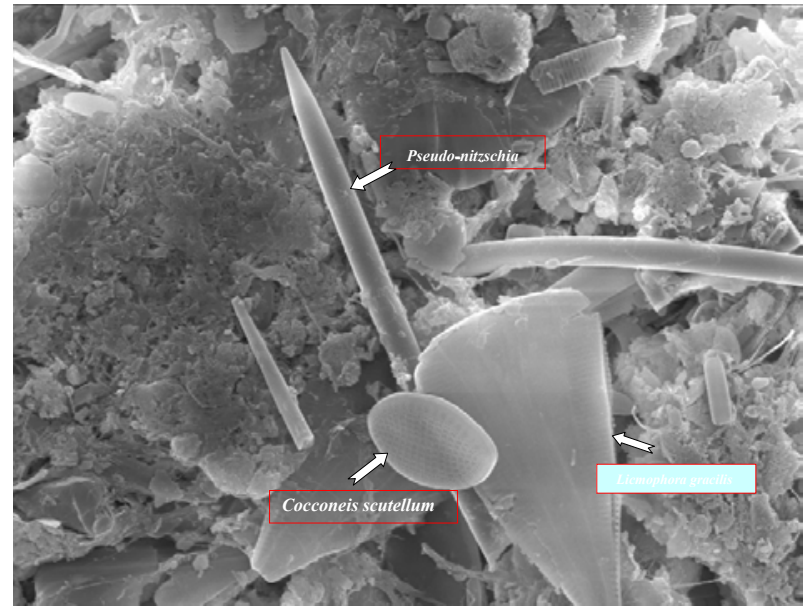

Figure 7: Pseudo-nitzschia galaxie related to Domoic Acid in sea water (Amnesic ShellfishPoisoning or ASP).

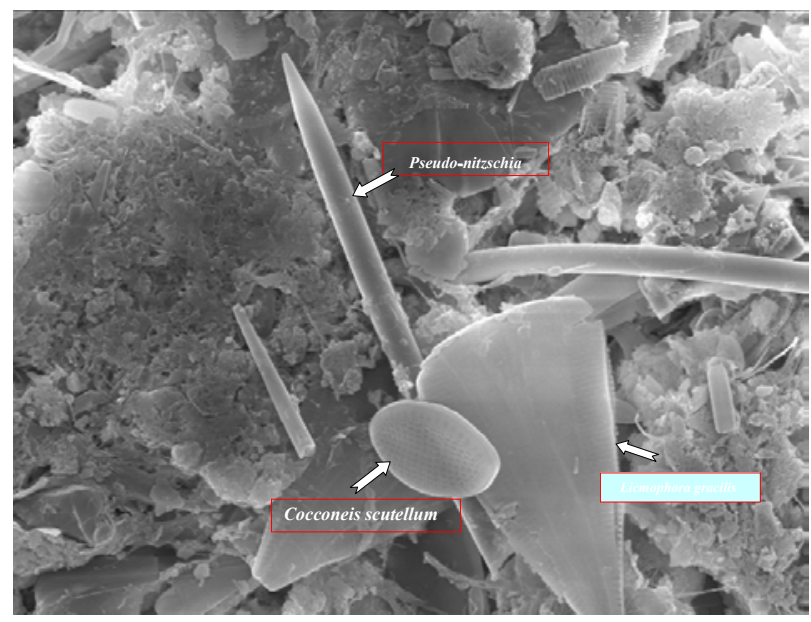

Figure 8: Pseudo-nitzschia galaxie, Cocconeis scutellum and Licmophora gracilis in sea water.

performed using the Microtox ${ }^{\bullet}$ Model 500 Toxicity Analyzer from Microbics Corporation (AZUR Environmental) testing the duplicate sample using 3,5 Dichlorophenol as element reference toxicant in accordance with ISO 11348-3:2007 and paying attention to the quality of data as described by Ledda et al. [17]. The sample toxicity is expressed in $\%$ and is the mean of two readings at each sample, then the average is made of three aliquots sampled.

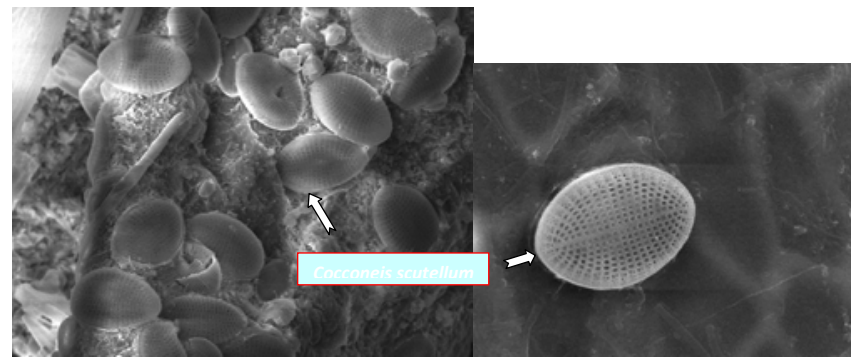

Figure 9: Cocconeis scutellum in magroalgae sampled in Acicastello 2009 and structure of its Frustule (see zoom), no toxicity reported.

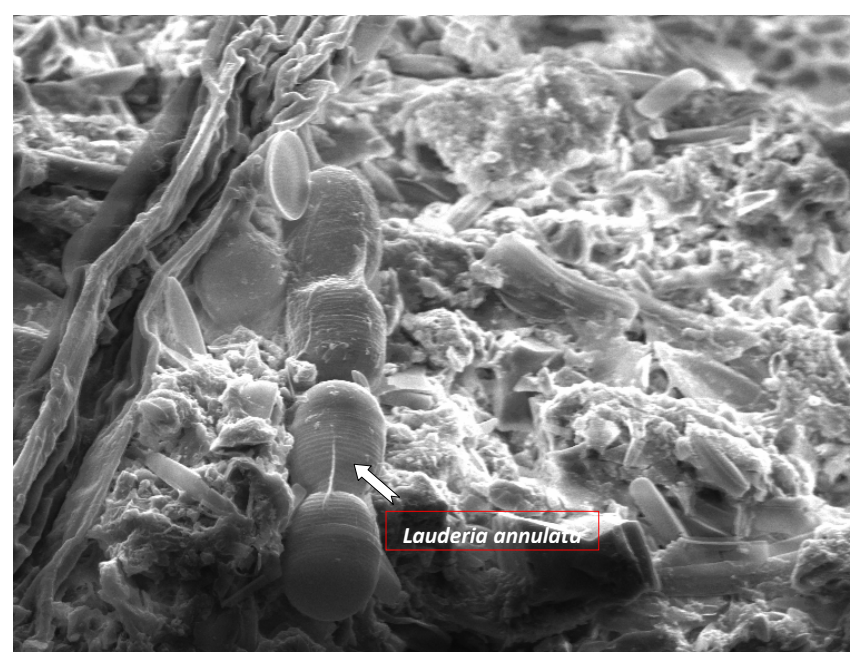

Figure 10: Lauderia annulata in magroalgae sampled in Acicastello 2010, no toxicity reported.

The SEM recognition of phytoplankton species found was carried out according to the manual "Guide to the recognition of the plankton of the Italian seas" [18]. The number of phytoplankton cells was determined in according to Utermöhl method [19].

\section{Results and Discussion}

The O. ovata was not observed in the various sampling sites in the three years investigated, while peaks of diatoms have been highlighted in a not appropriate season in all the samples tested, $(>1.000 \mathrm{cell} / \mathrm{mL}$ Level 1 of action indicated by WHO), especially in sites next to urban and industrial sewage rich in nutrients (Figure 2), however toxicity it was not detected by Vibrio fischeri test. 
Citation: Oliveri Conti G, Ledda C, Zuccarello M, Fiore M, Phallic R, et al. (2011) Detection of Ostreopsis ovata from Eastern Sicily Coast Using SEM microscopy coupled to the Vibrio fischeri Test Development J Aquac Res S4: 001. doi:10.4172/2155-9546.S4-001

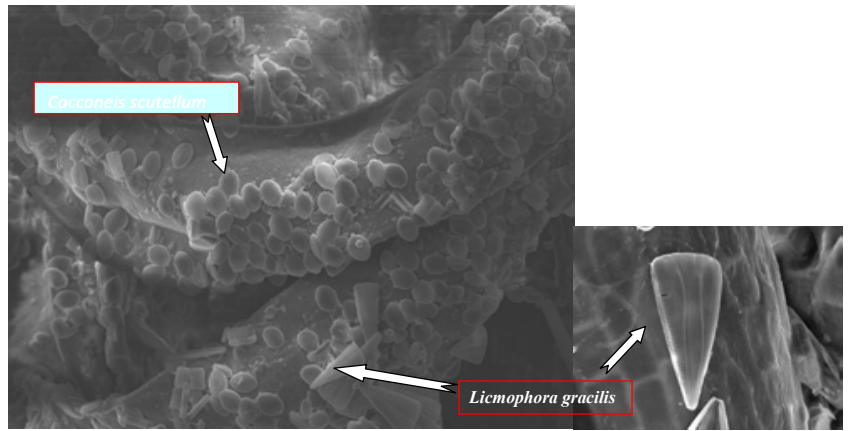

Figure 11: Licmophora gracilis in magroalgae sampled in Capo Mulini 2010 and structure of its. Frustule (see zoom), no toxicity reported.

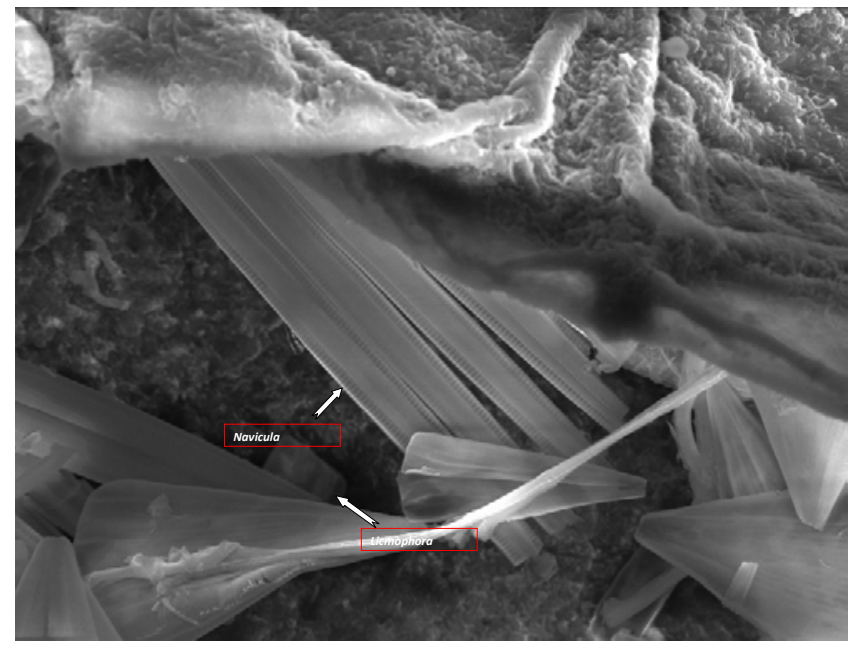

Figure 12: Navicula peregrina e Licmophora gracilis in magroalgae sampled in Playa 2010.

Only in three sampling sites (water from Scogliera July-2008, Playa August-2009 and Capomulini July-2009) the toxicity tests were positive respectively $45 \%, 29 \%$ and $28 \%$ (see Figure 3). Only in the water from Scogliera July-2008 the diatoms are found to be absent (Figure 4). It is hypothesized that the toxicity might be attributed to the presence of some colonies, respectively: Coolia monotis for water from Scogliera July-2008, where the microanalysis showed the Silica absence (Figure 5 and Table 1) which gave us an absolute certainty that were not diatoms compared to a micro-analysis conducted on a diatom (Figure 6 and Table 2), tables 1 and 2 with figure 5 and 6 explicate the micro-analysis report, these show a difference of Si concentration in diatom. In the water sample from Playa August-2009 (Figure 7) and Capomulini July2009 (Figure 8) has been detected a minor number of diatoms, but also the presence of some individuals of Pseudo-Nitzschia (toxic diatomea). This toxicity, in our opinion, could be attributed either to an overuse of algaecide by the manager of the nearby bathing establishment, but pershap also at the presence of Pseudo-Nitzsche although it was far too poor $(<150 \mathrm{cell} / \mathrm{ml})$ to justify the toxicity of the water sampled. To give strength to our hypothesis was the lack toxicity in samples of Capomulini June, August and September 2008 tested in the same sampling site when absent the Pseudo-Nitzsche. Further studies are underway in order to elucidate the chemical structure and properties of the possible toxicant compound detected in the samples toxic in by liquid chromatography and mass spectrometry.
All samples of macroalgae observed by SEM showed an abundance of diatoms in the number and species such as Cocconeis scutellum (Figure 9), Lauderia annulata (Figure 10), Licmophora gracilis (Figure 11), Navicula peregrina (Figure12) and many more, but absence of $O$. ovata.

Our monitoring has revealed that the algal blooms are not a very frequent problem for the Ionian coast, but instead it's occasional blooms, the evidence of this derives from the identification of different species in different sites, but especially in periods different from each other.

Through this study was therefore possible to show that the Ionic seawater in coast of the province of Catania city, although in the past have been the subject of alerts and reports HABs, do not show an immediate risk to the health of the resident population and for economy related to the fish, shellfish and mussels. The identification of some toxic species, however, although not significant in number, in any case represent a risk that it may become an emergency o bloom under specific environmental and climatic conditions $[4,8,13]$. To protect the potentially exposed people's health is necessary to continue the monitoring and complete the preventive action through an adequate public information. It should finally be pointed out that the expansion of these species during the last years, their occurrence in massive blooms in the Mediterranean Sea constitute them as a potential threat for human health. It is therefore evident that a routine monitoring strategy for these benthic species is essential in susceptible areas.

\section{References}

1. Barlaan EA, Furukawa S, Takeuchi K (2007) Detection of bacteria associated with harmful algal blooms from coastal and microcosm environments using electronic microarrays. Environ Microbiol 9: 690-702.

2. Watkins SM, Reich A, Fleming LE, Hammond R (2008) Neurotoxic Shellfish Poisoning. Mar Drugs 6: 431-455. DOI: $10.3390 / \mathrm{md} 20080021$.

3. Hallegraeff GM (1993) A review of harmful algal blooms and their apparent global increase. Phycologia 32: 77-99.

4. Peperzak $L$ (2005) Future increase in harmful algal blooms in the North Sea due to climate change. Water Sci Technol 51: 31-36.

5. Hégaret H, Da Silva PM, Wikfors GH, Haberkorn H, Shumway SE, et al. (2011) In vitro interactions between several species of harmful algae and haemocytes of bivalve molluscs. Cell Biol Toxicol 27: 249-266.

6. Sellner KG, Doucette GJ, Kirkpatrick GJ (2003) Harmful algal blooms: causes impacts and detection. J Ind Microbiol Biotechnol 30: 383-406.

7. Ade P, Funari E, Poletti R (2003) Risk to human health associated with marine toxic algae. Ann Ist Super Sanita 39: 53-68.

8. Ferrante M, Ledda C, Cunsolo MA, Fiore M, Fallico R, et al. (2010) Harmfu algal blooms in Italy and their health effects in the population. Ig Sanità Pubb 66: 649-658.

9. Ministero Della Salute. Dipartimento della Prevenzione e della Comunicazione. Direzione Generale della Prevenzione Sanitaria. Ufficio IV. Linee guida Gestione del rischio associato alle fioriture di Ostreopsis ovata nelle coste italiane. Documento approvato dal Consiglio Superiore di Sanità nella seduta del 24 maggio 2007. Dr. Salvatore Squarcione.

10. ISPRA (Superior institute for environmental protection and research) Monitoraggio di Ostreopsis ovata e altre microalghe potenzialmente tossiche lungo le coste italiane nel triennio 2007-2009. ISPRA, Rapporti, n. 127/2010. ISBN 978-88-448-0469-5.

11. Icardi G, Marensi L (2005) Aspetti epidemiologici - Proceedings of Internationa Conference "Ostreopsis: problema per il Mediterraneo?"Genova.

12. Mattei D, Melchiorre S, Messinneo V, Bruno M (2005) Diffusione delle fioriture algali tossiche nelle acque italiane: gestione del rischio ed evidenze epidemiologiche. Roma: Istituto Superiore di Sanità (Rapporti ISTISAN 05/29)

13. G, Borghini B, Camici G, Casotti M, Righini P et al. (2003) Fioriture algali di Ostreopsis ovata (Gonyaulacales. Dinophyceae): un problema emergente. Biologia Ambientale 17: 17-23. 
Citation: Oliveri Conti G, Ledda C, Zuccarello M, Fiore M, Phallic R, et al. (2011) Detection of Ostreopsis ovata from Eastern Sicily Coast Using SEM microscopy coupled to the Vibrio fischeri Test Development J Aquac Res S4: 001. doi:10.4172/2155-9546.S4-001

14. Tognetto L, Bellato S, Moro I, Andreoli C (1995) Occurence of Ostreopsis ovata (Dinophyceae) in the Tyrrenian Sea during summer 1994. Botanica marina 38: 291-295

15. Ferrante M, Oliveri Conti G, Ledda C, Zuccarello M, Bella F, et al. (2009) First results about a monitoring Ostreopsis ovata along the coast of the province of Catania (Sicily-Italy). Epidemiology 20: S159.

16. Vitale DG, Brundo MV, Viscuso R (2011) Morphological and ultrastructura organization of the male genital apparatus of some Aphididae (Insecta, Homoptera). Tissue Cell 43: 271-282. Jun 22. [Epub ahead of print].
17. Ledda C, Oliveri Conti G, Fiore M, Fallico R, Sciacca S, et al. (2011) Measurement uncertainty for the determination of the inhibitory effect on Vibrio fischeri: A practical approach. Journal of Environmental Chemistry and Ecotoxicology 3: 139-141.

18. Avancini M, Cicero AM, Di Girolamo I, Innamorati M, Magaletti E, et al. (2006) Guida al riconoscimento del plancton dei mari italiani. Vol. I Fitoplancton. Programma di monitoraggio per il controllo dell'ambiente marino costiero. Ministero dell'Ambiente e della Tutela del Territorio e del Mare. 2006, ICRAM.

19. Utermöhl H (1958) Zur Vervollkommung der quantitativen PhytoplanktonMethodik. Mitt Int Ver Limnol 9: 38.
This article was originally published in a special issue, Phyłoplankłon community responses and Harmful Algal Blooms handled by Editor(s). Dr. Paul V. Zimba, Texas A\&M University-Corpus Christi, USA. 